\title{
Understanding Mind through Indian Psychology
}

\author{
Sreeja Gangadharan $\mathrm{P}^{1 *}$, S P K Jena ${ }^{2}$
}

\section{ABSTRACT}

Mind is a subject widely studied under various discipline, yet, failed to come up with a definition which we could comprehend. These studies had unravelled a number of questions regarding the nature of the mind and leads to serious debates on its composition, i.e., whether it consists only of higher intellectual functions such as memory and reasoning, its activities i.e.; what is the relationship of mind and body, is dualism or monism?, is it accessible to study or only an endeavour of first person and finally, who possess a mind?; do all beings have a mind or only human beings could possess it?, and so on. With two simple models, 'the Epistemological dualism' and the model of 'Mind-Spirit; dichotomy Vs coexistence' based on the concepts in Indian Psychology, the paper throws more light in to the subject mind and its faculty.

Keywords: Mind, Dualism, Monism, Consciousness, Spirit and Indian psychology

Although the subject mind is widely studied under various disciplines such as Philosophy, Religion, Psychology and Cognitive Science there is neither a comprehensive definition nor a general consensus on its attributes. In layman's sense, mind is attributed to thoughts or if we go by dictionary, it is "that part of a person which makes it possible for him or her to think, feel emotions and understand things" or it is "the element of a person that enables them to be aware of the world and their experiences, to think, and to feel; the faculty of consciousness and thought". But, don't you think that, these definitions are a bit complex for the human mind to comprehend, since it leads to more questions than answers or really do our mind is all these? With two simple models, 'the Epistemological dualism' and the model of 'Mind-Spirit; dichotomy vs. coexistence' the paper throws more light in to the subject mind and its faculty.

To go a little in to the background of studies in mind we could see a lot of debates are already happened and are still going on about its attributes; what makes up a mind, its activities i.e., whether it consists only of higher intellectual functions such as memory and reasoning, is it accessible to study or only an endeavour of first person; what is the relationship of mind and

\footnotetext{
${ }^{1} \mathrm{Ph}$. D. Scholar, Department of Psychology, University of Delhi, India)

${ }^{2}$ Professor, Department of Psychology, Delhi University, South Campus, India

*Responding Author

(C) 2016 I S Gangadhran, S Jena; licensee IJIP. This is an Open Access Research distributed under the terms of the Creative Commons Attribution License (http://creativecommons.org/licenses/by/2.0), which permits unrestricted use, distribution, and reproduction in any Medium, provided the original work is properly cited.
} 


\section{Understanding Mind through Indian Psychology}

body (Patricia Smith,1989; Hart, 1997), is it dualism or monism? (Plato, 1995) and finally who possess a mind; do all beings have a mind or only human beings could possess it, with the latest advancement in the Artificial Intelligence the question further extends its conventional boundary and asks do machines could also possess mind? (Russell, et al. 2003). Addressing each of these questions opens a new arena which is equally complex.

But the subject is simply and beautifully explained in Indian Psychology. With the help of two models the 'Epistemological dualism' and the model of 'Mind-Spirit; dichotomy v.s coexistence its further simplified and explained here in this paper. This model considers mind as a interface between two sources of knowledge, and these two sources are;

(a) the knowledge about the world which is acquired through ones senses and

(b) the knowledge from one's own consciousness.

Hence we could says that there exists two different sources of knowledge to which the mind has access to,

1) Transactional Knowledge, which involving mind as an interface between the brain and sensory system and,

2) Transcendental Knowledge which connects with the consciousness.

This could be further explained with the help of a model called model of epistemological dualism or two state model of knowledge and awareness.

\section{The Model of Epistemological Dualism/ Two state model of knowledge and awareness}

As depicted in fig 1, the model consists of two different sources of knowledge to which the mind has access to; the transactional knowledge and the transcendental knowledge. As against the Western bio-centric model, this model is based on the concepts in Indian Philosophy, which considers consciousness as the primary principle irreducible to the brain states. It says that brain does not generate consciousness; it simply reflects consciousness and often by filtering, limiting and embellishing it (Rao, 2008). From this we could understand consciousness lies somewhere in the primary level or above the level of brain or cognitive process.

The model further says, mind is interfacing instrumentally and connects consciousness at one end and body at the other end. When it connects with the world outside through sensory system, we get phenomenal awareness, when it connects with consciousness we have transcendental realization. When mind is consumed by sensory data consciousness is a reflecting source; if one empties this sensory data one could access consciousness there arises the unmediated direct knowledge where the knower and the knowledge blend harmoniously.

Here the concept of dualism is attributed to two sources of knowledge or two levels on which mind operates i.e., 'Transactional knowledge' and 'Transcendental knowledge' hence this model explains the two way exchange of information, with mind as an interface. Whereas the concept 


\section{Understanding Mind through Indian Psychology}

of dualism explained by Descartes focuses on distinguishing mind and the brain and Descartes identified mind with consciousness and self awareness (Descartes, René , 1998).

In Indian Philosophy, this epistemological dualism has a profound impact for higher level learning called Nididhyasana i.e. meditative learning, and is possible only when, the mind withdraws from participating in sensory process, then it would be in a position to access consciousness there arises the unmediated direct knowledge. If one asks what is the purpose of such knowledge or why man needs it? then, the answer is so simple since this is the only way one could overcome the sufferings and raise oneself to a higher level of awareness and achievement.

As the Upanishads says, ‘to know Brahman is to be Brahman’ and the purpose of the Upanishads is to reveal 'Brahman', the supreme 'self'. And this is the existential quest for every man and consciousness is the ground condition for this awareness.

Why we need to know this supreme 'self'? This is because, Upanishads says, 'atma' or 'self' (consciousness) is responsible for the activities of the 'manas', (or mind) and mind only plays a secondary role in knowledge. This is why neurological studies are often insufficient to give a complete understanding of the human nature since this phenomenological aspect of consciousness remains the "hard problem" (Chalmers, 1996).

\section{The Model of Epistemological Dualism}

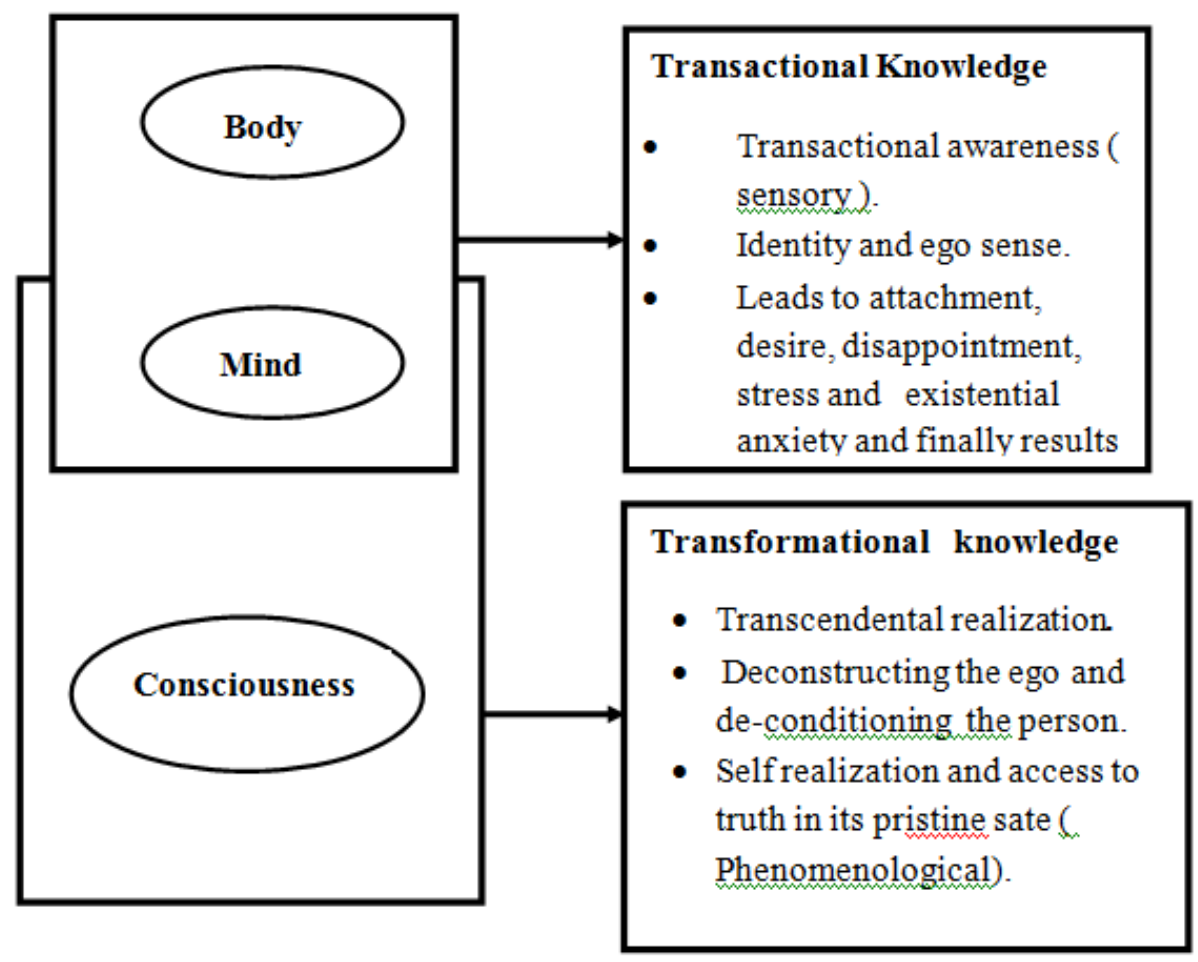

Fig1: Illustrates the model of Epistemological Dualism.

(c) The International Journal of Indian Psychology, ISSN 2348-5396 (e)| ISSN: 2349-3429 (p) | 114 


\section{Understanding Mind through Indian Psychology}

Due to the glaring gaps in our knowledge in the way human thinks, feel and act, contemporary psychologists had reduced a person to just brain driven machine and believes ones achievements and actions, beliefs and behavior, cognition and conduct can be studied objectively. This gap in our knowledge is unbridgeable without altering the current models, since the activities with in the domain of mind is something restricted to the first person and is not directly accessible to others and they could interpret only what the owner consciously or unconsciously communicate with the researcher or to a third person. Hence consciousness which is largely left out of the main stream psychology needs a better attention ( Rao, 2008). The model of Epistemological dualism based on the concepts in Indian Philosophy clearly depicts this.

Indian Psychology, which evolved thousands of years before is rooted in religion and philosophy. Indian Psychology defines the Psyche or self as the product of Sravana, Manana and Nididyasana; which means, sense driven learning (Sravana literally means hearing, at Vedic times it is hearing the truth from the Guru's mouth, and could be interpreted as sensory processed information such as perceptual learning), intellectual understanding and intuitively obtained realization respectively (Rao, 2008). Hence an individual is a composite of mind, body and consciousness and could be studied from three different levels.

\section{Method of Study}

Since, a person is a composite of Mind, body and consciousness, the method of study explains the three different levels in the study of an individual.

The three different levels in the study of an individual

\begin{tabular}{|l|l|l|l|}
\hline Dimensions & First Person & Second Person & Third person \\
\hline $\begin{array}{l}\text { Nature of } \\
\text { Knowledge }\end{array}$ & $\begin{array}{l}\text { Intuitive(Nididhyasana } \\
\text { /Meditative) }\end{array}$ & $\begin{array}{l}\text { Mind constructed } \\
\text { Cognition (Manana) }\end{array}$ & $\begin{array}{l}\text { Sense driven } \\
\text { (Sravana) }\end{array}$ \\
\hline Method of Study & $\begin{array}{l}\text { Indirectly by observing } \\
\text { transformational } \\
\text { consequences }\end{array}$ & $\begin{array}{l}\text { Introspection } \\
\text { observation }\end{array}$ \\
\hline Reflects in & $\begin{array}{l}\text { Perfection in thoughts and } \\
\text { action }\end{array}$ & Directs actions & Directs action. \\
\hline
\end{tabular}

Table 1: Shows 3 operational levels of an individual and its various dimensions

Indian Psychology says, 'Sravana', which is third-order knowledge could be objectively recorded and verified and could be obtained through observation, experiment and physical measurement. 'Manana', the mind constructed cognition is the first person experience hence introspective observation and second person technique could be employed. Nididyasana, the meditative knowledge is utterly subjective and ineffable, it is experiential and trans cognitive state and hence, could neither be observed nor shared with others, could only be understood by 


\section{Understanding Mind through Indian Psychology}

indirectly observing the transformational consequences on the person who is presumed to be in that state (Rao, 2008). The tools and techniques in western Psychology could explore an individual in his third and second level only. But this may not complete the study of an individual, since it could not reaches to the first level, which is more phenomenological. (Constrained by its bio centric bias, noted behaviourist J, B. Watson (1913) had waged a war to remove consciousness from psychological dictionary.)

The most appropriate starting and ending points in the journey of human enquiry towards the ultimate goal in one's life is this first person i.e., consciousness. This could be explained with the help of another model called Mind-Spirit: Dichotomy Vs Coexistence.

\section{Mind-Spirit: Dichotomy vs. Coexistence}

Spirit is the final and the original involutional element. Mental human beings are not aware of the soul or spirit which controls or mould his actions. Thus spirit, which is concealed by mind and body, also manifests through them. An inner evolution helps to attain supreme reality which reveals oneself to the luminous consciousness and will provide unlimited reach and intensity of love, joy and beauty (Rao, 2008). This could be compared to the need for self actualisation described by Maslow in his need hierarchy. This eternal element is nature's intention and the Spirit should be powerful enough to transform its instrument (mind) to attain this eternal happiness. Eventually, the spirit will exist as something greater than mind as the original and primal evolutionary element. This is depicted in the figure below.

\section{Mind- Spirit: Dichotomy vs. Coexistence}

1. Spirit as the original involution element.

\section{Manifestation of spirit} through Mind.

3. Spirit as the final evolutionary element.

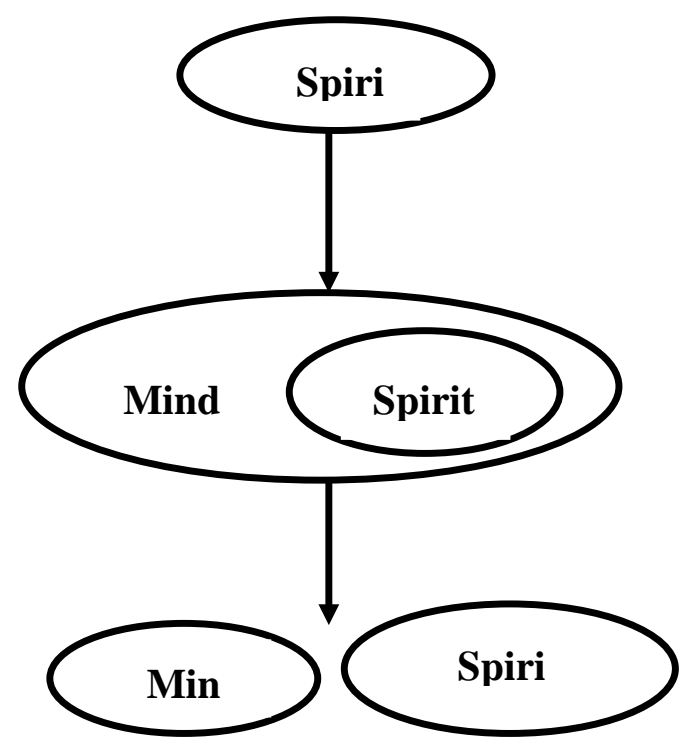

\section{Fig 2: Evolutionary transformation of Spirit}




\section{Understanding Mind through Indian Psychology}

\section{CONCLUSION}

The mind, the most complex concept in Psychology is always a mystery to all the discipline which had tried to gain a mastery over it. Throughout the history the subject was open to serious debates on its nature, faculties and even its identity. The paper employs a totally different approach with the help of two models to explain the subject, mind. The two models, Epistemological dualism' and the model of 'Mind-Spirit; dichotomy vs. coexistence are based on the concepts of mind in Indian Philosophy and it simplifies the understanding of the mind.

The first model, Epistemological dualism says, that mind is an interface between two different levels of knowledge, the transactional knowledge at one level and transformational knowledge at other level. If the mind is open to the world outside through its sense organs then it is filled with transactional knowledge but if the mind is open to the world inside it gains access to the consciousness there arises the transformational knowledge. Hence to understand a person fully, a researcher should gain access to these three levels, but with the currently available tools in psychology one could access only up to two levels and the first person level could be studied only through transformational consequences.

\section{REFERENCE}

Atreya, J.P, (1985), “Mind and Its Functions in Indian Thought”, New Delhi: Classic Publishing Company.

Bem, S. \& Looren de Jong, H, (1997), “Theoretical issues in Psychology: An Introduction”. London: Thousand Oaks, New Delhi: Sage.

Berry, J. W., Poortinga, Y. H., Segall, M. \& Dasen, P. R, (1992), “Cross-Cultural Psychology: Research and Applications”, Cambridge, UK: Cambridge University Press.

Charlmers, D.J. (1996). “The Conscious Mind: In search of a Fundamental Theory”, Philosophy of mind series. New York: Oxford University Press.

Churchland, P.S.(1989), "Neurophilosophy: towards a unified science of the mind-brain”, MIT Press.

Dalal,A., K. (2002). "Psychology in India: A historical Introduction”. In: G. Misra and A. K. Mohanty (Eds.) "Perspectives on indigenous Psychology”. New Delhi: Concept Publication Company.

Descartes, René (1998), “Discourse on Method and Meditations on First Philosophy”, Hacket Publishing Company. ISBN 0-87220-421-9.

Gergen, K.J., Gulerce, A.,Lock,A., \&Misra, G.(1996). "Psychological science in cultural context”. American Psychologists, 51(5), 496-503.

Hart, W. D. (1997): 'Dualism’, Guttenplan, S. (ed.), “A Companion to the Philosophy of Mind, Blackwell”. pp. 265-7.

Kuppuswamy, B. (1985). “Elements of Ancient Indian Psychology”. New Delhi: Vikas.

Levine, J. (1983). “Materialism and qualia: The explanatory gap”. Pacific Philosophical Quarterly, 64, 354-361.

Pinel, J, (1990), “Psychobiology”, Prentice Hall, Inc. ISBN 88-15-07174-1 


\section{Understanding Mind through Indian Psychology}

Rama, S., Ballentine, R., Ajaya, S. (1976), "Yoga and psychotherapy: The evolution of Consciousness". Pennsylvania: Himalayan Institute Press.

Rao, K. R. (2002), “Consciousness Studies: Crross Cultural Perspectives”. Jefferson, NC: McFarland.

Rao, K. R. (2008), “Hand Book of Indian Psychology”, Cambridge University Press, pp. 1-19.

Sinha, J. (1933/1958), "Indian Psychology", Vol. 1- Cognition. New Delhi: Matilal Banarasidass.

Watson, J. B. (1913), “Psychology as the behaviourist views it”. Psychological Review, 20. pp. 158-177.

How to cite this article: S Gangadhran, S Jena (2016), Understanding Mind through Indian Psychology, International Journal of Indian Psychology, Volume 3, Issue 3, No. 11, DIP: 18.01.201/20160303, ISBN: 978-1-365-21307-6

(c) The International Journal of Indian Psychology, ISSN 2348-5396 (e)| ISSN: 2349-3429 (p) | 118 